\title{
PROPERTY AND THE STATE OR 'THE FOLLY OF TORRENS': A COMPARATIVE PERSPECTIVE
}

\author{
DANIEL FITZPATRICK, ${ }^{*}$ CAROLINE COMPTON** AND JOSEPH FOUKONA***
}

\begin{abstract}
Australian lawyers often extol the virtues of the Torrens system as a means to secure property in land. Yet, the comparative evidence of benefits is mixed and context-dependent, particularly in terms of the nature, provenance and capacity of the state. This article analyses ways in which positivist land laws, including Torrens systems of title by registration, create legal understandings of property that are tied closely to projections or assumptions of state territorial authority. The intertwining of property and sovereignty constructs allodial conceptions of property based on possession or custom as subordinate, if not illegal, simply because they exist in social orders that lie beyond the administrative systems of the state. As a result, there is a chronic fragmentation of legal and social understandings of property in areas of the world with Torrens law and large numbers of informal settlements. The case studies include the Philippines and the Solomon Islands.
\end{abstract}

\section{INTRODUCTION}

A number of contemporary property scholars have responded to positivist property paradigms by emphasising the relationality of property and the social obligations of property law. ${ }^{1}$ Some works reassess property from the perspective

* $\quad$ BA LlB LlM (Syd), PhD (ANU); Professor, Faculty of Law, Monash University, Melbourne, Australia. Fieldwork for this article was undertaken pursuant to a Discovery Project (DP130104802) and a Future Fellowship (FT110101065) from the Australian Research Council.

** BA (Hons) (UNSW), MEd (UTS), JD (Hons), GDLP PhD (ANU); Research Associate, UNSW Law, University of New South Wales, Sydney, Australia.

*** LLB LLM PDLP (USP), LLM (VUW), PhD (ANU); Senior Lecturer, School of Law, University of the South Pacific, Port Vila, Vanuatu.

1 See, eg, Gregory S Alexander et al, 'A Statement of Progressive Property' (2009) 94(4) Cornell Law Review 743, 743-4. 
of values such as democracy, ${ }^{2}$ human dignity, ${ }^{3}$ and human rights. ${ }^{4}$ Others have a concern for property at the margins - the eviction of households under discriminatory regimes, ${ }^{5}$ or the significance of rights to exclude for the excluded. ${ }^{6}$ Others again aim to de-centre the dominant ontology of formal state law, through studies of legal pluralism and property, ${ }^{7}$ indigenous ontologies of property,${ }^{8}$ or the conceptualisation of property in terms of belonging, identity and place. ${ }^{9}$ This article contributes to progressive property scholarship not so much in terms of alternative ontologies of property, but as a deconstruction of the ontology of statist property law itself. Adopting a comparative approach, ${ }^{10}$ the article analyses ways in which positivist land laws, including Torrens systems of title by registration, create legal understandings of property that are tied closely to projections or assumptions of state territorial authority. The intertwining of property and sovereignty constructs allodial conceptions of property based on possession or custom as subordinate, if not illegal, simply because they exist in social orders that lie beyond the administrative systems of the state. ${ }^{11}$ As a result, there is a chronic fragmentation of legal and social understandings of property in areas of the world with Torrens law and large numbers of informal settlements.

Positivist or statist principles of property law include rules that freehold ownership derives from or through sovereign grant, that 'waste land' belongs to the state, and that prescribed instruments are necessary to create or transfer property in land. The global spread of title-by-registration laws further reduces the significance of allodial or natural rights sources of proprietary entitlement, not only in terms of rules favouring registered over unregistered interests, but also in relation to claims based on adverse possession or acquisitive prescription. ${ }^{12}$ Title-

2 Joseph William Singer, 'Democratic Estates: Property Law in a Free and Democratic Society' (2009) 94(4) Cornell Law Review 1009.

3 Gregory S Alexander, 'The Social-Obligation Norm in American Property Law' (2009) 94(4) Cornell Law Review 745.

4 Hanoch Dagan and Avihay Dorfman, 'The Human Right to Private Property' (2017) 18(2) Theoretical Inquiries in Law 391.

$5 \quad$ AJ van der Walt, Property in the Margins (Hart Publishing, 2009).

6 Eduardo M Peñalver, 'Property as Entrance' (2005) 91(8) Virginia Law Review 1889; Eduardo Moisés Peñalver and Sonia K Katyal, Property Outlaws: How Squatters, Pirates, and Protesters Improve the Law of Ownership (Yale University Press, 2010).

7 See generally Franz von Benda-Beckmann, Property in Social Continuity, Continuity and Change in the Maintenance of Property Relationships through Time in Minangkabau, West Sumatra (Martinus Nijhoff, 1997) $120-7$.

8 See generally Irene Watson, Aboriginal Peoples, Colonialism and International Law (Routledge, 2015).

9 See Sarah Keenan, Subversive Property: Law and the Production of Spaces of Belonging (Routledge, 2015).

10 This aspect of the work draws on works on world legal history: see, eg, Lauren Benton and Richard J Ross (eds), Legal Pluralism and Empires, 1500-1850 (New York University Press, 2013) 1, 8. As John Lovett points out, much of the recent scholarship on progressive property draws on United States cases, and the global comparative dimensions of this work contribute new material to debates on progressive property: John A Lovett, 'Progressive Property in Action: The Land Reform (Scotland) Act 2003' (2011) 89(4) Nebraska Law Review 739, 740.

11 Although beyond the scope of this work, there is also potential for resilient property orders such as indigenous systems to be classified as subordinate, or illegal, even in strong state circumstances.

12 See, eg, Daniel Fitzpatrick, 'Fragmented Property Systems' (2016) 38(1) University of Pennsylvania Journal of International Law 137, 186. 
by-registration laws closely connect property in land to the administrative systems of the state - in ways which exclude marginalised people who conceptualise proprietary or possessory entitlements through allodial orders beyond the margins of state territorial control. ${ }^{13}$ In this sense, the global phenomenon of property informality is not simply a function of poverty, migration and urbanisation, or government capacity to supply serviced land, but of land laws which construct conceptualisations of ownership based on legal fictions of sovereign control over human relationships with land. These circumstances arise with particular force in the Global South, where colonial legal orders co-opted land laws to construct the territorial authority of European sovereigns, and overlaid title-by-registration laws which provided a veneer of legal certainty notwithstanding enduring circumstances of contestation both over the provenance of state formation, and the nature and derivation of proprietary entitlements to land.

Much of the following critique is directed at Torrens rules of title-byregistration and their effects on allodial orders beyond the administrative systems of the state. The critique acknowledges that Torrens laws vary and may include rules of possession, priority and equity that ameliorate some, but not all, of the exclusionary impacts of title-by-registration rules. However, the focus of analysis is not so much the typologies of Torrens law, but the co-option of positivist laws such as Torrens to construct or project the authority of sovereign territorial states. In this sense, the critique of Torrens law is intended to illustrate a broader problem of conceptual entanglements among property, territory and sovereignty that arose, or at least strengthened, as a result of colonial circumstances of invasion and occupation. These entanglements extend beyond Torrens to include principles that tie freehold property to sovereign grant, and restrict claims of adverse possession or prescription against the sovereign. The key argument, therefore, is that sovereign-centred property law - exemplified but not limited to Torrens rules constructs legal understandings of property that do not reflect the social reality of proprietary practices in many postcolonial jurisdictions of the Global South.

The article is structured as follows. Part II sets out comparative evidence of relationships between property informality and state-centric laws of title by registration. Part III provides a case study of the Philippines - where claims of ownership based on possession are excluded by Torrens-type laws and colonial doctrines of sovereign title to land. Part IV provides a case study of town lands in the Solomon Islands - where claims of ownership based on possession or custom are excluded by Torrens laws which vest indefeasible title in the Crown. The case studies demonstrate that the effects of Torrens-type laws depend closely on the nature, provenance and capacity of the state. For many postcolonial states, in particular, the co-option of land law to construct claims of sovereign territorial order has created conceptual frames for property which are maladapted to regulation of property-related practices at or beyond the margins of state control.

13 As a matter of terminology, this article uses terms such as allodial, proprietary and possessory to describe the nature of relationships with land within property orders beyond the administrative systems of the state. Such terms are an aid to analysis, particularly as to circumstances of marginalisation through law, and are not intended to deny cultural constructions of relationships with land that may not be captured by use of these terms. 
In all Parts, the article presents evidence of social understandings of property based on possession or custom which are rendered illegal or informal by the operation of state-centric Torrens laws, even though their claimants are long-term occupiers or users with perceptions of entitlements recognised by neighbours and even at times local government officials. While these entitlements resist the binary in rem/in personam distinctions of European law, they still have proprietary characteristics based on social practice which extend far beyond simple legal classifications of trespass, or personal licences terminable at the will of the landowner.

\section{STATIST TORRENS LAWS AND THE GLOBAL SPREAD OF INFORMALITY}

This Part briefly describes the growth of informal settlements in postcolonial jurisdictions of the Global South. The analysis highlights social understandings of property in informal settlements, not only through circumstances such as custom or long-term possession, but also through documentary dealings in land. As the case studies illustrate, these social practices are embedded in ordering mechanisms based on family, community or group; but are not recognised by legal rules that connect freehold rights to sovereign grant, or require prescribed instruments of dealing to create or transfer legal interests in land. Further, as a matter of priorities, they are rendered subordinate to sovereign title, or registered interests in land, even where there are accommodative rules of equity or possession/prescription. The net result is a chronic fragmentation of social and legal understandings of property in proprietary orders that exist beyond the control of the state. In legal terms, informal settlers are excluded from first registration where the state or another entity has a better title. Informal dealings are void at law due to absence of title, or serve at best to pass a lesser form of possessory or equitable interest. Finally, as a practical matter, even registrable dealings are not registered because of citizens' disconnection from the state. For all these phenomena, there is evidence of persistence over long periods of time notwithstanding the projections of state authority constructed by sovereign-centric laws relating to land.

The reality of property in many, if not most, postcolonial jurisdictions of the Global South is far removed from the assumptions of legal certainty presented by proponents of positivist property law. In 2012, UN-Habitat estimated that over 850,000 people - or around $33 \%$ of the total metropolitan population of developing regions - lived in urban informal settlements. ${ }^{14}$ In rural areas, Fitzpatrick provides evidence that 'hundreds of millions live on land claimed by the state in agricultural, pastoral and forested areas'.$^{15}$ Even for households with registered rights to land, there is evidence from some jurisdictions that large numbers continue to follow localised methods of land conveyancing, notwithstanding land laws that mandate registration of title transfers. ${ }^{16}$ There is further evidence that 
large numbers of informal settlers have relationships with land which have proprietary characteristics, at least in terms of elements such as long-term possession, transferability, social recognition and investment in housing or production. To provide three brief illustrations: a number of studies highlight the long-term nature of many informal settlements - with some such as larger favela in Brazil now in existence for over 100 years. ${ }^{17}$ Other studies highlight the family networks which lead to practices such as informal subdivisions or extra-legal rental agreements. ${ }^{18}$ Other studies again highlight the emergence of land markets in informal settlements involving subdivisions, agreements to rent or transfer, and even evidentiary use of non-proprietary documentation from local governments (eg utility bills, house numbers and voting enrolments). ${ }^{19}$

Informal land market documentation often involves local governments as informal mechanisms interact with elements of the formal sector ${ }^{20}$ For example, in Jakarta a survey of informal settlements found that only $5.3 \%$ of respondents had no form of government-issued documentation, with most holding letters of sale witnessed by the local 'village' head, or letters of occupation issued by the local subdistrict head..$^{21}$ Further types of semi-formal documentation in Indonesia include letters of acknowledgement of land right issued by the village or subdistrict head. All these documents are used as evidence in dealings which are not registered with the National Land Agency. ${ }^{22}$ In India, evidence of entitlements to land in informal land markets include ration cards, identity cards, tax receipts and electricity bills. ${ }^{23}$ Some states of India provide written undertakings that settlements defined as 'slums' will not be removed for 10 years, notwithstanding an absence of legal rights to land. ${ }^{24}$ In Brazil, illegal subdivisions known as loteamentos involve contracts of sale from purported landowners, and receipts for

17 Edesio Fernandes, 'Providing Security of Land Tenure for the Urban Poor: The Brazilian Experience' in Alain Durand-Lasserve and Lauren Royston (eds), Holding Their Ground: Secure Land Tenure for the Urban Poor in Developing Countries (Earthscan Publications, 2002) 101, 108. In 2003 over 40\% of slum residents in Kolkata, India had occupied their land for two generations or more: United Nations Human Settlements Programme, The Challenge of Slums: Global Report on Human Settlements (2003) 213 ('The Challenge of Slums Report').

18 For a description of 'backyard shacks' and family rental processes in South Africa: see, eg, Lauren Royston, 'Security of Urban Tenure in South Africa: Overview of Policy and Practice', in Alain DurandLasserve and Lauren Royston (eds), Holding Their Ground: Secure Land Tenure for the Urban Poor in Developing Countries (Earthscan Publications, 2002) 165-79.

19 See Gustaaf Reerink, 'Land Registration Programmes for Indonesia's Urban Poor: Need, Reach, and Effect in the Kampongs of Bandung' in Janine M Ubink, André J Hoekema and Willem J Assies (eds), Legalising Land Rights: Local Practices, State Responses and Tenure Security in Africa, Asia and Latin America (Leiden University Press, 2009) 527, 529, 537.

20 As a general rule, the issue and use of local government documentation is more prevalent in cases of illegal subdivision than unlawful occupation: see Alain Durand-Lasserve and Lauren Royston,

'International Trends and Country Contexts - From Tenure Regularization to Tenure Security', in Alain Durand-Lasserve and Lauren Royston (eds), Holding Their Ground: Secure Land Tenure for the Urban Poor in Developing Countries (Earthscan Publications, 2002) 1 ('International Trends and Country Contexts').

21 Raymond J Struyk, Michael L Hoffman and Harold M Katsura, The Market for Shelter in Indonesian Cities (Urban Institute Press, 1990) 93-5.

22 Ibid.

23 Durand-Lasserve and Royston, 'International Trends and Country Contexts' (n 20) 25.

24 Ibid 24. 
payment of land tax, which then form the basis for further transfers of the land, even though the land office will not register the accompanying deed..$^{25}$

The foregoing examples suggest that informal land markets are resistant to legal transformation even though the law may prescribe documentary forms for the conveyance of transfer of interests in land. Although requirements for prescribed documentation pre-date the development of Torrens law, Torrens system requirements of title by registration through prescribed instruments illustrate with some clarity the extent of differences in social and legal understandings of property that may arise where law fails to reflect or transform persistent social practice. The first example is Cambodia. As a result of recommendations by World Bank-appointed Australian lawyers, the Land Law 2001 (Cambodia) adopts the Torrens principle that transfers of title have proprietary effect only as a consequence of registration of the title. ${ }^{26}$ Yet, according to one study, only around 2,000 subsequent registrations had taken place out of a total of 605,000 titles issued under a World Bank systematic titling program. ${ }^{27}$ Another study identified a widespread belief that documents acknowledging possession of land, issued by local commune officials and required for first registration of titles, were in and of themselves sufficient to establish proprietary rights to land. ${ }^{28} \mathrm{~A}$ UN-Habitat survey further found that around $75 \%$ of unregistered landholders in Phnom Penh believe they are legal owners of their land. ${ }^{29}$ In these types of land market circumstances, and particularly in Cambodia where there is no common law legacy to provide rules of equity, the title by registration requirements of Torrens law exacerbates divergences among social and legal understandings of property. This is particularly the case as future purchasers or transferees of land have no rights to their land at law, unless they apply for first-time registration, because their purported vendors or transferors do not match the names of the registered proprietors on the title register.

Cambodia provides a case where rules of equity did not accompany the transplant of title by registration law. Moreover, although the law recognises possessory interests, including as a basis for first registration, no claim of acquisitive prescription lies against the public or private lands of the state. ${ }^{30} \mathrm{In}$ these circumstances, it might be argued that rules of equity and prescription would ameliorate the disenfranchising effects of title by registration law - both in terms of informal dealings and claims to long-term possession of state land. However,

25 Ibid. Regarding the use of land tax declarations as a standard evidentiary basis for extra-legal land transfers: see also Babette Wehrmann and Danilo R Antonio, 'Intermediate Land Tenure: Inferior Instruments for Second-Class Citizens?' [2011] (1) Land Tenure Journal 5. Concerning the use of informal land sale affidavits as alternatives to notarised documentation in South Africa: see Karol Bourdreaux and Paul Dragos Aligica, Paths to Property: Approaches to Institutional Change in International Development (Institute of Economic Affairs, 2007) 60-3.

26 Land Law 2001 (Cambodia) art 65. The effects of land law in Cambodia are discussed further in Fitzpatrick (n 12).

27 Mark Grimsditch and Nick Henderson, Untitled: Tenure Insecurity and Inequality in the Cambodian Land Sector (Report, 2009) 42.

28 Chi Mgbako et al, 'Forced Eviction and Resettlement in Cambodia: Case Studies from Phnom Penh' (2010) 9(1) Washington University Global Studies Law Review 39, 46-7.

29 The Challenge of Slums Report (n 17) 222.

$30 \quad$ Land Law 2001 (Cambodia) art 29. 
the core problem of tenure insecurity and land grabbing in Cambodia is not so much the design choices of Torrens law, but the way in which land law took on positivist characteristics - exemplified by Torrens rules - which were aimed at constructing the territorial authority of the post-peace agreement state. This positivist entanglement of property and the state is illustrated by a further rule in Cambodia's land law providing that land without an owner belongs to the state. ${ }^{31}$ In combination with title by registration law, the default rule of state title allows the state to argue that, notwithstanding social understandings of property based on possession and exchange, those without registered titles lack lawful rights to their land. ${ }^{32}$

Kenya provides a second example involving allodial property systems based on custom. ${ }^{33}$ The Registered Land Act 1962 establishes the Torrens principle that a registered proprietor of land obtains indefeasible title, subject to interests recorded on the register and overriding interests set out in the Act. ${ }^{34}$ Yet, a number of studies of rural areas suggest that large numbers of registered owners do not comply with requirements to register dealings or transfers of estates in land, particularly in cases of testamentary succession involving communal or lineage interests. Lineage land involves customary obligations to extended family members - so much so that in one survey of a district in Western Kenya $87 \%$ of respondents agreed it was 'inconceivable' that a registered proprietor would attempt to expel (unregistered) lineage members from family land, and only $4 \%$ agreed they would move willingly in the event of attempted expulsion. ${ }^{35}$ These circumstances create a broad reluctance to update the titles register in cases of succession. For example, Simon Coldham cites an estimate from the Kaimbu District that in the early 1960s over 3,000 titles remained registered in the names of deceased persons notwithstanding legal requirements to register interests acquired by heirs. ${ }^{36}$ Coldham further notes only around 3.4\% of deceased estates in East Kadianga had been registered in the name(s) of heirs. ${ }^{37}$

The Kenya example involves circumstances of subsequent rather than first registration of interests in land. While unregistered testamentary successions may take effect in equity, the point of the Kenya case is not so much one of subordination - where embedded social practices are classified as inferior in a context of Torrens priorities - but rather that customary systems themselves may be resistant to laws which mandate registration of prescribed instruments of transfer in state-managed systems of cadastral administration. In this sense, the Torrens system in Kenya exemplifies the assumptions or projections of state

31 Ibid art 12.

32 Natalie Bugalski, 'Housing Rights Litigation in Cambodia: The Boeung Kak Lake Case' (2008) 5(4)

Housing and ESC Rights Law Quarterly 1, 4.

33 The effects of land law in Kenya are discussed further in Fitzpatrick (n 12).

34 Registered Land Act 1962 (Kenya) ch 300 s 27.

35 HWO Okoth-Ogendo, 'The Perils of Land Tenure Reform: The Case of Kenya' (Research Paper, University of Nairobi, 1986) 8.

36 Simon FR Coldham, 'Land-Tenure Reform in Kenya: The Limits of Law' (1979) 17(4) Journal of Modern African Studies 615, 618, citing FD Homan, 'Succession to Registered Land in the African Areas of Kenya' (1963) 2(1) Journal of Local Administration Overseas 49, 50. 
authority over land which lie behind positivist systems of land law. Although it is the case that law may extend proprietary recognition beyond the registration systems of the state, through rules of equity or possession, the assumption remains that landholders will migrate to state systems simply because of the relative legal security of a registered title. The fact that this has not occurred in Kenya highlights the argument that proprietary orders beyond the reach of the state are still constructed as subordinate, notwithstanding their persistence as a matter of social practice, because land law is based on core positivist assumptions of the apex proprietorial authority of a state.

Title-by-registration laws assume a state that has the legitimacy and capacity to require or induce landholders to register proprietary rights to land. ${ }^{38}$ Yet, comparative evidence suggests that a number of postcolonial governments, particularly those with borders that are products of European state agreements, have never had the capacity or legitimacy to maintain or extend administrative systems of land administration for reasons of cost, corruption and resistance from alternative systems of quasi-proprietary ordering. ${ }^{39}$ Where Torrens laws tie legal interests in land to the administrative reach of the state, the effect is to subordinates at best, or to construct as illegal, property orders that are disconnected from the registration systems of the state. These circumstances cause chronic disconnections between social and legal understandings of property at the peripheries of state control. Where there is weakness, incapacity or illegality on the part of the state, social or allodial understandings of property develop on the basis of concepts such as possession, custom, transactions and family or community networks, and persist notwithstanding labels of illegality, or categorisations as subordinate, because of weakness or incapacity on the part of the state. This proposition is supported by the following case studies of the Philippines and Solomon Islands.

\section{THE PHILIPPINES}

The papal bull Inter Caetera, issued by Pope Alexander VI on 4 May 1493, purports to 'give, grant, and assign' to the Spanish Crown in perpetuity all islands and mainlands 'found and to be found, discovered and to be discovered', in order to 'lead the peoples dwelling in those islands and countries to embrace the

38 For examples where 'modern' government perspectives have been imposed on local populations without replacing non-state mechanisms of ordering: see generally Mitchell Dean, Governmentality: Power and Rule in Modern Society (Sage Publications, $2^{\text {nd }}$ ed, 2010) 89-116.

39 Describing the stages of application of 'European' land laws to Commonwealth Africa: see Patrick McAuslan, Bringing the Law Back In: Essays in Land, Law, and Development (Ashgate, 2003) 59-83; Sally Falk Moore, 'Changing African Land Tenure: Reflections on the Incapacities of the State' (1998) 10(2) European Journal of Development Research 33. For examples in Indonesia: see Franz von Benda-Beckmann, Property in Social Continuity: Continuity and Change in the Maintenance of Property Relationships in Minangkabau, West Sumatra (Martinus Nijhoff, 1979). For Ghana: see Christian Lund, Local Politics and the Dynamics of Property in Africa (Cambridge University Press, 2008). For British colonies in Africa: see Sally Engle Merry, 'Review: Law and Colonialism' (1991) 25(4) Law \& Society Review 897, 918. 
Christian religion' ${ }^{40}$ Francisco de Vitoria, a Professor of Theology at the University of Salamanca, who famously set out a number of propositions concerning sovereignty and title to land in a 1557 lecture, ${ }^{41}$ argued that the papal bull did not grant title to the Spanish Crown over lands held by native Indians simply as a result of 'discovery'. ${ }^{42}$ Vitoria set out a series of propositions with resonances of natural law justifications for property, beginning with the notion that native Indians had legitimate title to their lands because dominion over things is a gift of God. ${ }^{43}$ Discovery, therefore, could not be a basis for Spanish title as the Indians were owners of their land, and had not chosen to surrender sovereignty or title. ${ }^{44}$

These circumstances of debate over sovereignty, territory and property provide context for the 1681 compilation of laws known as the Recopilación de Leyes de las Indias ('Recopilación'). ${ }^{45}$ The Recopilación was a four-volume compilation that sought to systematise all laws relating to the Spanish Indies (including the Philippines). The compilation included a number of laws purporting to protect native possessory rights to land, and to exclude rights to land from the grant of encomienda - which was a right to collect tribute from indigenous persons living in a particular area on their conversion to Catholicism. A range of other laws also purported to protect the welfare of indigenous subjects. At the same time, the Recopilación set out a foundational rule of Crown title to land, which has since been reproduced in the Constitutions of the independent Republic of the Philippines. ${ }^{46}$ This rule - later known as the Regalian doctrine - vested all land 'held without proper and true deed of grant' in the Spanish Crown, and provided that, after 'distributing to the natives what may be necessary for tillage and pasturage', land was 'free and unencumbered' for disposal by the Crown, save for land reserved for public and common use. ${ }^{47}$

Both the United States Supreme Court, ${ }^{48}$ and the Philippines Supreme Court, ${ }^{49}$ interpret the Regalian doctrine as defining land in the public domain to include all lands not acquired from the government, either by purchase or by grant. As a consequence, there is no allodial source of private ownership of land in the

40 Jennifer Reid, Religion, Postcolonialism, and Globalization: A Sourcebook (Bloomsbury Publishing, 2014) $15,16$.

41 Francisco de Vitoria, 'The First Relectio of the Reverend Father, Brother Franciscus de Victoria on the Indians Lately Discovered', tr John Pawley Bate in James Brown Scott (ed), The Spanish Origin of International Law (Clarendon Press, 1934) app A [trans of: De Indis et de Jure Belli Relectiones (1696)]. Ibid xxiv-xxv [359]-[360].

43 Ibid v-vii [315]-[318].

44 Ibid xxv [360].

45 Recopilación de Leyes de las Indias 1680 (Spain).

46 Regarding vesting ownership of all lands in the public domain in the state: see, eg, Philippines Constitution 1987 art XII(2). For a discussion of Constitutional restatements of the Regalian doctrine: see Oswaldo D Agcaoili, Property Registration Decree and Related Laws: Land Titles and Deeds (Rex Bookstore, 2006) 4-6.

47 Recopilación de Leyes de las Indias 1680 (Spain) Law 1 Title 12 Book 4, quoted in Valenton v Murciano, GR No 1413, 30 March 1904, 3 Philippine Reports 537 (Willard J) (Supreme Court of the Philippines).

48 The state remains the absolute owner of land until an applicant based on possession provides proof and obtains a deed of title from the state: Cariño v Insular Government, 212 US 449, 458, 461-2 (1909).

49 See Agcaoili (n 46) 2-3 (summarising Supreme Court jurisprudence on the Regalian doctrine). 
Philippines, except perhaps for claims under the Indigenous People's Rights Act $1997 . .^{\circ}$ Those who claim ownership of land as a result of possession or custom, without intermediation by the state, have no proprietary rights to their land. While, as is discussed below, possession may be a basis for presumptions of title, in the absence of a better right, the title of ownership must derive directly or indirectly from sovereign grant. It goes without saying that these legal principles are a distinct departure from the natural law propositions of Vitoria. Notably, as well, they are similar to earlier common law formulations of the radical title of the Crown, such as the statement by Blackstone that 'the King is the universal lord and original proprietor of all the lands in his kingdom; and that no man doth or can possess any part of it, but what has mediately or immediately been derived as a gift from him'. ${ }^{51}$

As with the common law, law of the Philippines adopts a number of mechanisms to protect the proprietary interests of possessors of land. For example, article 539 of the Civil Code of the Philippines ('Civil Code') provides that 'every possessor has a right to be respected in [their] possession; and ... shall be protected in or restored to said possession by the means established by the laws and the Rules of Court' ${ }^{52}$ Article 434 further provides that a plaintiff 'must rely on the strength of [their] title and not on the weakness of the defendant's claim'. ${ }^{33}$ That is: there is no defence of third party rights (jus tertii) in an action against a possessor, and the issue for determination is who has the better right, rather than who has the best right. The Civil Code further sets out a presumption of ownership arising from actual possession 'under claim of ownership'. ${ }^{54}$ As a result, a wrongfully dispossessed owner may not resort to self-help, and must prove their own title in order to sustain an action to recover possession. ${ }^{55}$

In all these respects, save for the absolute prohibition on self-help by a dispossessed owner, the Civil Code aligns with principles of possession as a

50 Indigenous People's Rights Act 1997 (Philippines) s 56 ('IPRA') ('property rights within the ancestral domains already existing and/or vested upon effectivity of this Act, shall be recognized and respected'). A number of Filipino commentators have queried whether property rights 'recognised and respected' under the IPRA are allodial in nature, or remain part of the patrimonial property of the state under the Regalian doctrine. In Cruz v Secretary of Environment and Natural Resources, GR No 135385, 6 December 2000, the Supreme Court of the Philippines reached a split decision (7:7) in relation to a petition challenging the constitutionality of the IPRA on the basis that the recognition of indigenous title to lands contravened Constitutional provisions concerning the Regalian doctrine. While the act was deemed valid as there was no majority decision, the question whether native title under the act is allodial or forms part of the patrimonial property of the state until there are acts of recognition remains unresolved: Agcaoili (n 46) 6-8.

51 William Blackstone and William Draper Lewis, Commentaries on the Laws of England in Four Books, Book II, Of the Feudal System (Rees Welsh and Company, 1902-1915) 51-2. More modern formulations interpret the radical title of the Crown not as a form of proprietorship which extinguishes, solely on the basis of reception of the common law, allodial rights to land, but as a statement of the legal authority of the sovereign to grant estates or interests in land, and to declare other land part of the Royal demesne: see further Mabo v Queensland [No 2] (1992) 175 CLR 1. See also Samantha Hepburn, 'Feudal Tenure and Native Title: Revising an Enduring Fiction' (2005) 27(1) Sydney Law Review 49. Civil Code of the Philippines, Republic Act No 386 of 1949, art 539.

53 Ibid art 434.

54 Ibid art 433.

55 Ibid art 434. 
proprietary right in the common law relating to real property. However, the Civil Code departs from the common law in relation to principles of adverse possession. According to the Supreme Court, there is an 'iron-clad dictum' that neither adverse possession nor acquisitive prescription lie against the state in relation to public domain land because of the Regalian doctrine and its Constitutional counterparts. ${ }^{56}$ The prohibition applies to all types of land in the public domain, even patrimonial property claimed under the Regalian doctrine, unless there has been a declaration through legislation or presidential proclamation that the land is no longer required for public use. ${ }^{57}$ Further, the Presidential Decree No 1529 Amending and Codifying the Laws Relative to Registration of Property and for Other Purposes 1978 (Philippines) ('Property Registration Decree'), a Torrens law which is discussed further below, provides that claims of prescription or adverse possession do not lie against registered proprietors of interests in land. ${ }^{58}$ Such a provision is consistent with some, but not all, Torrens laws in the states of Australia. ${ }^{59}$ In the Philippines, however, the combined effect of the Regalian doctrine and the Property Registration Decree is to extend the areas in which long-term possessors have no claims of proprietary rights to all lands in the archipelago, save for areas outside the public domain which are not registered under the Property Registration Decree.

\section{A Torrens Law in the Philippines}

Shortly after acquisition of sovereignty from the Spanish, the United States introduced the Land Registration Act 1903 ('Land Registration Act'), which overlays Torrens system principles of title by registration on the civil law notary requirements of the Civil Code. ${ }^{60}$ The act establishes a Court of Land Registration 'which shall have the exclusive jurisdiction of all applications for the registration ... of title to land ... within the Philippine Islands' ${ }^{6}{ }^{61}$ The act then sets out a number of Torrens system principles. First, there is a rule of indefeasibility of registered title. Applicants receiving a certificate of title 'shall hold the same free of all encumbrance except those noted on said certificate'. ${ }^{62}$ Second, there is the socalled mirror principle. The certificate of title is conclusive evidence both of interests in land recorded on the certificate and of the description of the land itself. ${ }^{63}$ Third, there is a rule of title by registration:

$[\mathrm{N}] \mathrm{o}$ deed, mortgage, lease or other voluntary instrument, except a will, purporting to convey or affect registered land, shall take effect as a conveyance or bind the

\footnotetext{
56 Alonso v Cebu Country Club Inc, GR No 130876, 5 December 2003 (Supreme Court of the Philippines). 57 Civil Code art 420(2).

58 Presidential Decree No 1529 Amending and Codifying the Laws Relative to Registration of Property and for Other Purposes 1978 (Philippines) s 47 ('Property Registration Decree').

59 See generally Fiona Burns, 'Adverse Possession and Title-by-Registration Systems in Australia and England' (2011) 35(3) Melbourne University Law Review 773, 777-803.

60 Land Registration Act 1903 (Philippines) ('Land Registration Act'). See Civil Code arts 1356, 1358.

61 Land Registration Act s 2.

62 Ibid s 39.

63 Ibid s 47.
} 
land, but shall operate only as a contract between the parties ... The act of registration shall be the operative act to convey and affect the land. ${ }^{64}$

According to Justice Oswaldo Agcaoili, the Land Registration Act 'is said to be almost a verbatim copy of the Massachusetts Land Registration Act 1898, which, in turn, followed the principles and procedure of the Torrens system of registration formulated by Sir Robert Torrens ... in South Australia' . ${ }^{65}$ The Torrens principles of the act have now been replicated in the Property Registration Decree.

The Land Registration Act is somewhat unusual in so far as judicial adjudication is a preliminary step to title registration. The court's decree as to title is final and conclusive except in cases of fraud and a number of paramount interests. ${ }^{66}$ However, even in cases of fraud, the applicant for review must file a petition within one year of entry of the decree. Further, the re-opening of the decree within the one-year period is subject to the exception that 'no innocent purchaser for value has acquired an interest' in the land. If there is any such purchaser, 'the decree of registration shall not be opened, but shall remain in full force and effect forever'. ${ }^{67}$ These are strict provisions in so far as those who are denied unregistered interests by reason of fraud, and who fail to object prior to the court decree, have no claim to the land after one year or, in any event, against an (unregistered) innocent purchaser for value. ${ }^{68}$ Further, while a registered proprietor of an interest in land is subject to specified paramount interests, including liens, claims and unregistrable rights of way, they are not expressly subject to common exceptions in other Torrens jurisdictions such as short-term leases. As noted, the act further provides that no title to registered land adverse to a registered owner shall be acquired by prescription or adverse possession. ${ }^{69}$

It is worth pausing here to assess the ambition of the Land Registration Act. The act was promulgated in the same year as the United States acquired sovereign authority over the Philippines upon the cessation of the Spanish-American War of 1898. The United States administration inherited Spanish administrative systems which controlled some parts, yet remained weak or contested in other parts, of the archipelago. Nevertheless, the act requires registration or recordation - in administrative systems established by foreign colonial orders - in order for the creation or transfer of interests in land to have proprietary effect. Except in the case of wills, those who do not register a dealing in registered land, or record a deed in unregistered land, do not obtain a right at law that is enforceable against third parties, including other interest holders in the land. ${ }^{70}$ As a result, those who

64 Ibid s 50.

65 Agcaoili (n 46) 8.

66 The decree of the court renders 'all the world' parties to the order: Land Registration Act s 35, and is 'conclusive upon and against all persons' so as to 'bind the land and quiet title thereto': at s 38 .

67 Ibid s 38, for a list of persons who may make applications see s 19.

68 The act retains a deeds registration system for lands which are not registered under the Torrens provisions of the act. However, contrary to common deeds registration system principles, the act requires registration of the deed as a precondition for proprietary validity, irrespective of the performance of the underlying contract of conveyance itself: ibid s 113 .

69 Ibid s 46.

70 As a mixed civil and common law jurisdiction, the law of the Philippines allows recognition of interests in land arising in equity notwithstanding a failure to register the interest under Torrens law: see, eg, the discussion of trusts in the context of Torrens law in Agcaoili (n 46) 310-11. 
purport to obtain title through unregistered dealings are unable to transfer proprietary rights at law through further dealings in the land. This is the case even in circumstances where they are long-term possessors of the land who, along with other members of the community, consider that they hold proprietary rights as a consequence either of possession or the dealing.

In 1913, the Cadastral Act ${ }^{71}$ sought to supplement judicial processes for title registration under the Land Registration Act with administrative processes of registration by the Director of Lands. The Cadastral Act provides the basis for systematic registration of title as a result of very low rates of sporadic title registration under the Land Registration Act. In 1978, the Property Registration Decree combined the judicial and administrative title registration procedures under a compendious Torrens law. The Property Registration Decree retains the substantive Torrens principles set out in the Land Registration Act, while adding a number of ancillary provisions, including a process for judicial confirmation of imperfect or incomplete titles, ${ }^{72}$ and reconstitution of lost or destroyed certificates of title. ${ }^{73}$ The Property Registration Decree further provides a remedy of reconveyance for applicants with in personam claims in law or equity against the registered proprietor of an interest in land. ${ }^{74}$ The in personam remedy of reconveyance is available for as long as the estate in land has not passed to an innocent third party for value. Once there is performance of a conveyance to an innocent third party for value, the remedy for the aggrieved party lies in damages alone. ${ }^{75}$

\section{B Torrens Law and the Spread of Informality}

Very large numbers of landholders in the Philippines have not registered land under the Property Registration Decree and its antecedents; and, even in cases of registration, do not comply with the registration requirements of Torrens law. To take one example: by 1911, only 9,000 of an identified 2,250,000 parcels of land had been registered under the Land Registration Act. ${ }^{76}$ Even as at 2008, the Department of Environment and Natural Resources ('DENR') estimated that only $69 \%$ of land available for titling in the Philippines was registered, either through judicial or administrative titling, under the Property Registration Decree. ${ }^{.7}$ Registration rates apply only to land classified as alienable and disposable, which

71 Cadastral Act (Philippines) Republic Act No 2259 of 1913.

72 Property Registration Decree (Philippines) s 14(1).

73 Ibid s 110.

74 Ibid s 96. See also Narvasa v Imbornal, GR No 182908, 6 August 2014, 732 Supreme Court Reports Annotated 171 (Supreme Court of the Philippines).

75 See, eg, the discussion in Agcaoili ( $n$ 46) 293. These provisions replicate Australian law in terms of in personam claims in equity, but not necessarily in relation to in personam claims at law (where a prior legal estate may take precedence over the interest of the innocent purchaser for value up until the time of registration of that interest).

76 See OD Corpuz, The Roots of the Filipino Nation (Aklahi Foundation, 1989) vol 2, 528.

77 Department of Environment and Natural Resources (Philippines), Compendium of Basic Environment and Natural Resources (ENR) Statistics for Operations and Management $\left(2^{\text {nd }}\right.$ ed, 2008) 88. 
covers over $47 \%$ of the archipelago. ${ }^{78}$ The other $52 \%$ is classified as public domain land such as forests, mining, or national park land, and includes many millions of long-term residents classified as illegal or informal landholders. ${ }^{79}$ The application and effect of Torrens law is also undermined by significant failures to register transactions over registered land. ${ }^{80}$ One 2013 survey suggests that between 10$20 \%$ of titleholders do not register transactions concerning their land. ${ }^{81}$ Where there is registration, there is evidence of widespread loss, theft, damage, and illegal alteration of land records..$^{82}$ Yet, the Philippines persists with Torrens land title law and World Bank-assisted systematic land titling programs, notwithstanding - as is illustrated by the following discussion - their long-term failure to reflect social understandings of entitlements to land in extra-legal or informal settlements.

\section{Informal Urban Settlements in Manila and Tacloban City}

In less than 60 years following independence, the Filipino population increased more than fivefold from 19.2 million people in 1948 to 100.98 million in 2015. ${ }^{83}$ This growth was accompanied by a corresponding growth in urbanisation, from $36 \%$ of the population living in urban areas in the mid-1970s ${ }^{84}$ to urban residents comprising $51.2 \%$ of the population in $2015 .{ }^{85}$ Manila and the National Capital Region ('NCR') grew from 5.9 million residents in 1980 to 12.88 million residents by $2015 .{ }^{86}$ The population of Tacloban City increased more than $35 \%$ between 2010 and 2015, increasing from 179,000 to 242,000 residents. ${ }^{87}$ Further urban

78 Tony Burns, 'Land Administration Reform: Indicators of Success and Future Challenges' (Agricultural and Rural Development Discussion Paper No 37, World Bank, 2007) 29

$<$ http://siteresources.worldbank.org/EXTARD/Resources/ARDDiscussionPaper37.pdf>.

79 Emelyne V Talabis, 'Land Titling in the Philippines: Addressing Challenges Through a Reform-Oriented Framework' (Conference Paper, World Bank Conference on Land and Poverty, 20-24 March 2017) 3.

$80 \quad$ Land Registration Act ss 39, 50.

81 See Eleazar et al, Improving Land Sector Governance in the Philippines: Implementation of Land Governance Assessment Framework (Research Report, Land Equity Technology Services, Department of Environment and Natural Resources, World Bank, August 2013) 101.

82 See Tony Burns (n 78). For a comprehensive analysis of the state of the Philippines land administration: see ibid 92. For a description of a 'number of significant issues' in land administration in the Philippines, including that land descriptions in certificates of title are 'prone to error': see Carlos Isles and Berlin Berba, 'Philippines-Australia Land Administration and Management Project: Land Laws and Regulations Policy Study' (Research Report, Philippines Department of Justice, Land Equity International, July 2002) 8. Regarding documenting shortcomings in land administration infrastructure and capacity: see Gilberto M Llanto and Marife M Ballesteros, 'Land Issues in Poverty Reduction Strategies and the Development Agenda: Philippines' (Discussion Paper No 2003-03, Philippine Institute for Development Studies, March 2003) 7-10.

83 Philippine Statistics Authority, Highlights of the Philippine Population 2015 Census of Population (Report, 19 May 2016) <https://psa.gov.ph/content/highlights-philippine-population-2015-censuspopulation> ('2015 Census Highlights').

84 Agnes R Quisumbing and Scott McNiven, 'Migration and the Rural-Urban Continuum: Evidence from the Rural Philippines' (Discussion Paper No 197, International Food Policy Research Institute, October 2005) 1 .

85 Philippine Statistics Authority, Urban Population in the Philippines (Results of the 2015 Census of Population) (Web Page, 21 March 2019) <https://psa.gov.ph/content/urban-population-philippinesresults-2015-census-population>.

862015 Census Highlights (n 83).

87 'Population of Region VIII - Eastern Visayas (Based on the 2015 Census of Population)' Philippine Statistics Authority (Web Page, 2 June 2016) < https://psa.gov.ph/population-and- 
growth is anticipated by the government, which projects that more than $80 \%$ of the population will be urban residents by $2050 .{ }^{88}$ The Philippine government's National Informal Settlements Upgrading Strategy estimates there are more than 1.5 million informal settler households in the country, with some 600,000 families comprising more than 3 million people in Manila alone $-25 \%$ of the city's population - relying on informal housing. ${ }^{89}$ In Tacloban City, locally collected data suggests $11.7 \%$ of the city's 2015 population - about one in every nine people were informal settlers..$^{90}$ Informality in Tacloban, as in other places, tends to be highly localised with, for example, more than $80 \%$ of the residents of Barangay 6 being classified as informal. ${ }^{91}$

Despite the ongoing movement into urban areas, informal settlements tend to be highly durable and are often very long-lived. A 2003 UN-Habitat report noted that, on average, informal settlements in Metro Manila had been in place for 19 years, though there were settlements which had been in place for more than 40 years. ${ }^{92}$ Sixteen years later, a survey that covered three of Metro Manila's five cities showed that $54 \%$ informal settlers had been informal settlers for between 11 and 40 years, compared to $24 \%$ that had moved within the last five years. ${ }^{93}$ The longevity of informal settlements is significant because it illustrates the disconnection of law from long-term property relationships in urban informal settlements. In this case, the direct legal cause is the denial of claims based on adverse possession or prescription either against registered proprietors of land, or the state in relation to lands in the public domain. But it is also worth highlighting the broader legal history of sovereignty and property in the Philippines. The Philippines state relies on colonial doctrines to establish sole sovereign authority to issue freehold titles, and to claim as public domain or land without an owner. Although registered titles issued by the state are immune from adverse possession or prescription claims under the version of Torrens law applicable in the Philippines, the underlying problem of tenure insecurity in informal settlements is not one of Torrens design alone, but the ways in which the imagined authority of the state over property in land diverges from the long-term reality of informal settlements.

housing/title/Population \%20of\%20Region $\% 20$ VIII\%20-

\%20Eastern $\% 20$ Visayas $\% 20 \% 28$ Based $\% 20$ on $\% 20$ the $\% 202015 \% 20$ Census $\% 20$ of $\% 20$ Population $\% 29>$.

World Bank, 'Closing the Gap in Affordable Housing in the Philippines' (Policy Paper, National Summit on Housing and Urban Development, July 2016) 1

$<$ http://documents.worldbank.org/curated/en/547171468059364837/pdf/AUS13470-REVISED-PUBLICWBNationalHousingSummitFinalReport.pdf $>$.

89 Gayatri Singh and Gauri Gadgil, Navigating Informality: Perils and Prospects in Metro Manila's Slums (Report, 2017) x.

90 Partnership for Economic Policy, The Many Faces of Poverty (Report, 2014) vol 5, 153-4 $<$ https://www.pep-net.org/sites/pepnet.org/files/CBMS/Publications/CBMSPovertyMaps_Vol5_TaclobanCity.pdf $>$.

91 Ibid.

92 The Challenge of Slums Report (n 17) 215-6.

93 World Bank, Philippines Urbanization Review: Fostering Competitive, Sustainable and Inclusive Cities (Report, 2017) $62<$ http://documents.worldbank.org/curated/en/963061495807736752/Philippines-

Urbanization-review-fostering-competitive-sustainable-and-inclusive-cities $>$. 


\section{Informal Property Relationships in Tacloban City}

Fieldwork undertaken in a sito of Barangay 88, Tacloban City, ${ }^{94}$ in 2016 is illustrative both of the formation of informal settlements, and the ties of family, contract and investment that create community recognition of extra-legal rights to land. The 'first families' of the settlement were from an island fishing community in the neighbouring province of Samar. The families arrived in the early to mid1970s and were soon followed by other residents of the original community, attracted by fishing opportunities, access to markets, and (relatively) low cost land. The initial houses were described as 'fishermen's cottages', however as the residents made money they invested in more permanent housing on the land. The land was not purchased from anyone; rather the 'first families' staked a claim on unoccupied, and what would have been, at the time, undesirable land. As the settlement grew, it attracted other residents from other parts of Tacloban City and Samar, both the original village and otherwise, drawn to the area because of its access to the sea and low cost of living. Over time, an informal land market developed as houses were constructed and rented to 'newcomer' settlers, particularly in circumstances of cyclical migration where original settlers returned to Samar.

The longevity at the heart of the Barangay 88 community is reflected in the demographics of the community in 2016. Of 39 interviewed households, 11 were headed by a family member born in the original Samar village; six were headed by individuals born elsewhere in Samar and eight households were headed by people who had moved to the area from other parts of Tacloban City. Thirteen households, one third of those interviewed, were headed by people who first moved to the settlement between 1973 and 1986 - that is, between 30 to 43 years before the survey was conducted. Another five households had links to the settlement of between 20 and 30 years, and 10 households had been established between 10 and 20 years earlier. Only two of the households were headed by individuals who had been living in the settlement for less than a decade, one of whom had relocated to the settlement from the original Samar community to pursue educational opportunities in Tacloban. The remaining nine households were young families, the leaders of which reported being born and having lived their lives in the informal settlement in question.

\section{Property and Sovereignty in the Philippines}

To summarise, the Philippines Republic inherited a Torrens law that overlaid Spanish doctrines of Crown title to land. The legal result is unusually positivist in so far as Crown title is interpreted as akin to ownership, and Torrens law denies or restricts claims based on adverse possession or prescription, and claims based on in personam obligations of a registered proprietor. At the same time, the contemporary Philippines displays a high degree of property informality. There

94 Sitos are the smallest administrative unit in the Philippines, comprising a zone within the barangay; itself a sub-unit of a local government area. Semi-structured interviews were conducted in the sito concerned, Barangay 88, Tacloban City, between 4-8 July 2016. This was part of an ongoing research project on the site, conducted between February and August 2016. 
are relatively few applications for first registration of titles. There are very few applications to alter registered titles as a result of conveyance or inheritance; and there are large numbers of long-term informal settlements in urban areas. All these cases of informality have a common thread, namely persistent proprietary practices based on family relationships, community recognition, inputs of labour and investment, and the development of land markets. Understood in this sense, the problem of property informality in the Philippines is not so much a product of legal rules which restrict claims in equity or possession, but from the way in which law constructs or projects the idea of a sovereign territorial state in circumstances where the state is relatively weak, contested or perceived as illegitimate.

\section{THE SOLOMON ISLANDS}

Positivist requirements that freehold property derive from or through sovereign grant, or that land not subject of sovereign grant is owned by the state, supported European attempts to extend administrative controls as colonial policy shifted from evangelisation and protection of trade to economic production and territorial control. ${ }^{95}$ As the Philippines case suggests, European colonisation has played a critical role in the spread of state-centric postulates of land law to most parts of the decolonised Global South. The spread of Torrens-type laws through the Global South, particularly under the influence of neoliberal development programs, has further reduced the legal significance of acts such as possession, including through rules which exempt public land and registered private titles from claims based on adverse possession or acquisitive prescription. The effect has been a divergence of social and legal understandings of property in urban informal settlements of the kind found in the Philippines. The following case study of the Solomon Islands focuses further on Torrens law as a contributor to the global growth of informal settlements. Because the Solomon Islands was a protectorate rather than a colony of Great Britain, the case study allows analysis of the effect of Torrens law in the absence of Constitutional doctrines which vested ownership of all land in the sovereign.

\section{A The British Solomon Islands Protectorate}

The British Crown declared the British Solomon Islands Protectorate ('BSIP') over some of the islands that now form the Solomon Islands in $1893,{ }^{96}$ with the

95 For a description of the stages of application of 'European' land laws to Commonwealth Africa: see, eg, Patrick McAuslan, Bringing the Law Back In: Essays in Land, Law, and Development (Ashgate, 2003) 59-83.

96 Pacific Order in Council 1893 (UK) SR \& O 1893/78, ord 108. For proclamations made over the islands see Select Documents Relating to the Declaration of the British Solomon Islands Protectorate in 1893 and to the Extension of the Protectorate in 1897-1898 (UK) Western Pacific High Commission 8/III/28 (copy on file with authors). 
remaining islands claimed in 1898 and $1900 .{ }^{97}$ The terms of the 1893 declaration included the legal right of the Crown to prevent another European power from claiming sovereignty over the islands. At the time, the primary European competitor was Germany, which had agreed with Great Britain to divide the South Pacific into two spheres of influence in $1886 .{ }^{98}$ As a protectorate, there was no reception of the common law for indigenous inhabitants; ${ }^{99}$ and therefore, most likely no vesting of the radical title of the British Crown in the subject lands of the BSIP. ${ }^{100}$ The only basis for the Crown to claim title to land was through voluntary alienation and, after 1896, declarations of areas as waste land. ${ }^{101}$ In relation to waste land declarations, the Privy Council has held that annexations of territory are non-justiciable as an exercise of the prerogative powers of the Crown. ${ }^{102}$ In the event, therefore, the British Crown constructed claims of title to land in the BSIP notwithstanding the absence of radical title, or the accompanying legal fiction that possession of all land vested in the Crown at the time of sovereign acquisition. ${ }^{103}$

The British High Commission for the Western Pacific issued waste land declarations over a number of areas, particularly for plantations on the islands of Guadalcanal and Choiseul. ${ }^{104}$ Inevitably, as for example in the case of Tandai hunting territory in north-western Guadalcanal, ${ }^{105}$ lands declared as waste land were not regarded as unowned by local clan groups. ${ }^{106}$ This fact alone has contributed to ongoing conflict over conceptualisations of land ownership in the

97 See Select Documents Relating to the Declaration of the British Solomon Islands Protectorate in 1893 and to the Extension of the Protectorate in 1897-1898 (UK) Western Pacific High Commission 8/III/28 (copy on file with authors).

98 Paul W van der Veur (ed), Document and Correspondence on New Guinea's Boundaries (Australian National University Press, 1966). See BSIP Anglo-German Agreement 1899 Documents (UK) Western Pacific High Commission 8/III/30.

99 For a discussion of protectorates see Butterworth \& Co, Halsbury's Laws of England, vol 10 (at 1909) Dependencies, Colonies, and British Possessions, '1 Definitions and Classification' [858].

100 For a more detailed discussion see Sue Farran and Don Paterson, South Pacific Property Law (Cavendish Publishing, 2004) 38-9, noting in particular that as late as 1959 the Special Lands Commissioner recommended obtaining advice from the Colonial Office as to the nature of the Crown's radical title in the Protectorate: at 39.

101 See further Queen's Regulation 1896 (UK) SR \& O 1896/4 (restricting the alienation of land) and Queen's Regulation 1900 (UK) SR \& O 1900/3 (authorising declarations of waste land) (copies on file with authors).

102 Sobhuza II v Miller [1926] AC 518, 525 (Viscount Haldane for the Court); $R v$ Kent Justices; Ex parte Lye [1967] 2 QB 153, 176-7 (Lord Parker CJ), 181-2 (Salmon LJ); Post Office v Estuary Radio Ltd [1968] 2 QB 740, 753 (Diplock LJ).

103 See also Ian C Heath, 'Land Policy in Solomon Islands' (PhD Thesis, La Trobe University, 1979) 103-5.

104 Queen's Regulation 1896 (UK) SR \& O 1896/4 allowed lease of land by the High Commission of land which was 'vacant by reason of the extinction of the original native owners': at reg 10 . This provision was replaced by Queen's Regulation 1900 (UK) SR \& O 1900/3 reg 2, which defined waste land as land which was not 'owned, cultivated or occupied by any native'. The Solomons (Waste Land) Regulation 1904 (UK) SR \& O 1904/1 adopted the same restrictive definition. See also David Russell Lawrence, The Naturalist and His 'Beautiful Islands': Charles Morris Woodford in the Western Pacific (Australian National University Press 2014) 245-7 (providing a brief account of waste land declarations).

105 Rodolfo Maggio, “Honiara is Hard”: The Domestic Moral Economy of the Kwara'ae People of Gilbert Camp, Solomon Islands' (PhD Thesis, University of Manchester, 2014) 158.

106 See further Judith A Bennett, Wealth of the Solomons: A History of a Pacific Archipelago, 1800-1978 (University of Hawaii Press, 1987) 104 (discussing ad hoc determinations of waste land based on the appearance of non-use to British observers). See also Heath (n 103) 409-10. 
Solomon Islands. However, to focus on waste land declarations alone as mechanisms to construct sovereign territorial control would be to miss the private land acquisitions that formed the basis for most of the state's claims to land in the contemporary Solomon Islands. This is a point made by Martti Koskenniemi, who argues that private law dimensions of European colonisation have been overlooked by a public law focus on territorial sovereignty and the exercise of powers of eminent domain. ${ }^{107}$ The acquisition of land by European churches and trading interests, in particular, had a number of far-reaching consequences for postcolonial legal orders - including elevating the authority of purported 'native' representatives, creating conditions for enduring conflict over historical transfers of land, and separating European understandings of rights transferred through agreement from local understandings of entitlements to land. ${ }^{108}$ The following study of town lands in Honiara provides a related set of arguments: that the land acquisitions which drove many aspects of British colonisation in the Western Pacific contributed characteristics of enduring or recurring land conflict, contested constructions of authority for purported 'chiefs', and chronic divergences in legal and social conceptions of ownership in the contemporary Solomon Islands.

\section{B Indefeasibility of Title to Honiara Town Lands}

Prior to the BSIP, land in which the city of Honiara now stands was claimed under customary principles by the Tandai, Malango and Ghaobata tribal groups. ${ }^{109}$ Alienation occurred through a series of transactions. In 1886, purported representatives of the Lungga and Nanago sub-clans executed an agreement purporting to sell around 60 square miles of land now forming the main part of Honiara to three European traders for a small amount of trade goods. Subsequent parts of what is now Honiara were purchased from purported representatives of customary landowner groups by European trading interests in 1898 and 1910. ${ }^{110}$ These lands were purchased by the Levers Pacific Plantation Ltd ('Levers'), which sold part of their land to the colonial government in 1947 after the administrative capital was moved to Honiara. ${ }^{111}$ The initial town boundaries were created between 1953 and 1954, with subsequent extensions in 1973. ${ }^{112}$ Some land outside the town boundaries is classified as alienated land, and administered by the Provincial Government of Guadalcanal, while some is customary land held by Guadalcanal

107 Martti Koskenniemi, ‘Empire and International Law: The Real Spanish Contribution' (2011) 61(1) University of Toronto Law Journal 1, 2.

108 Ibid 3, 12, 27 (discussing ways in which the private law of colonisation helped to create the structures of power which informed notions of territorial sovereignty).

109 These tribal groups continue to assert their customary rights to land in and outside of Honiara: see Tony Hou and Donald Kudu, Solomon Islands: Honiara Urban Profile (United Nations Human Settlements Programme, 2012) 26.

110 For an overview, see Joseph Foukona, 'Urban Land in Honiara: Strategies and Rights to the City' (2015) 50(4) Journal of Pacific History 504, 510.

111 Ibid 510-11.

112 Ibid 512. As a matter of law, the town boundaries are now set by the Honiara City Act 1999 (Solomon Islands) sch 1 pt 1 as an area within the boundaries shown on Plan No 1981 Town Land (Honiara) Order 1973. 
landowner groups. ${ }^{113}$ As will be seen, the population of Greater Honiara has extended beyond the town boundaries through informal settlements, either without consent from customary land owners or through various forms of agreements with purported representatives of customary landowner groups. ${ }^{114}$

Under the Land and Titles Ordinance 1959 ('1959 Ordinance'), three separate titles to the town lands of Honiara were registered in the name of the Commissioner of Lands. ${ }^{115}$ The Crown thereby obtained the benefit of indefeasibility of title under the 1959 Ordinance, with the land registered as a perpetual estate on behalf of the Crown. ${ }^{116}$ Under the Land and Titles Act 1969, which is discussed below, the Commissioner of Lands is empowered to grant fixed term or perpetual estates from the registered perpetual estates to Honiara town lands. ${ }^{117}$ In the case of former Lever lands, the 1959 Ordinance further confirmed a title which had been upheld pursuant to the Solomons Land Claims Regulation 1923 (Solomon Islands) as a result of recommendations by a Commission of Enquiry established in 1919. ${ }^{118}$ Hence, in response to a 1963 claim on behalf of two lineages of Mataniko Village, which contested the registered estate of the Commission of Lands to parts of Honiara, the High Court of the Western Pacific found that (1) there was insufficient evidence to establish fraud or mistake as exceptions to the indefeasible title of the Commissioner under section 113(1) of the 1959 Ordinance; and (2) pursuant to the terms of the Solomons Land Claims Regulation 1923 (Solomon Islands) the title of the Levers was 'binding upon the parties affected' and 'shall have the force of law' as a result of the 1919 Commission of Enquiry recommendations. ${ }^{119}$

\section{The Land and Titles Act 1969}

The Land and Titles Act 1969 (Solomon Islands) ('Solomon Islands Act') establishes a Torrens system recommended by British advisors who had utilised, to a significant extent, Australian legal precedents to draft related legislation in British colonies of sub-Saharan Africa and South-East Asia. ${ }^{120}$ The act sets out a

113 See Ministry of Lands, Housing and Survey, Greater Honiara Urban Development Strategy and Action Plan (Main Report, July 2018) vol 1, 3 ('Greater Honiara Main Report').

114 Ibid.

115 The three separate titles were from 'three land leases from the $19^{\text {th }}$ century': Morgan Wairiu, 'History of the Forestry Industry in Solomon Islands: The Case of Guadalcanal' (2007) 42(2) Journal of Pacific History 233, 236.

116 See Foukona (n 110) 512.

117 See Land and Titles Act 1969 (Solomon Islands) s 132.

118 Official Transmission from Acting Resident Commissioner (British Solomon Islands) to Acting High Commissioner (Western Pacific), 24 January 1922, of Land Claim No 17, Matanikau, Kookoom Estate. This correspondence transmits a report on the claim: GG Alexander, Lands Commissioner, 24 January 1922, UASC, Western Pacific High Commission 4/IV, Western Pacific High Commission MP No 450/1922 (copy on file with authors). The recommendation by Alexander, confirmed by his successor Commissioner Phillips, included the return of some of the Lever lands to customary landowners.

119 In the matter of the Lands and Titles Ordinance 1959 and in the matter of certain questions reserved for consideration by the Court under s 113(1) thereof, Exhibit A, Civil Case No 3 of 1964, High Court of the Western Pacific, Civil Jurisdiction, available from Solomon Islands National Archives (copy on file with authors).

120 See generally Peter Brett, 'North Borneo: Redrafting the Land Legislation of Brunei' (1957) 6(4) American Journal of Comparative Law 565, 574, 576; Stanhope Rowton Simpson, 'Land Reform and Procedure' (1962) 1 Journal of Administration Overseas 84, 87. 
number of relatively standard Torrens principles. Registered interests in land are not to be created or disposed other than in accordance with the act. ${ }^{121}$ The disposal of any registered interest in land otherwise than in accordance with the act is 'ineffectual to create, extinguish, transfer, vary or affect any such interest'. ${ }^{122}$ The rights of an owner of a registered interest are indefeasible except as provided by the act. ${ }^{123}$ These exceptions are set out in section 229, which empowers the High Court to order rectification of the register where it is satisfied that registration was obtained or made by fraud or mistake. Section 229 further provides that the register shall not be rectified unless the registered owner 'had knowledge of the omission, fraud or mistake ... or substantially contributed to it'. ${ }^{124}$ No claim should be made on the basis of adverse possession against the Commissioner of Lands or local authority. ${ }^{125}$

As with the Philippines, the Solomon Islands Act provides more limited exceptions than contemporary Australian jurisdictions in relation to indefeasibility. In particular, there is no exception relating to short-term leases, which in Australian jurisdictions may bind a registered proprietor of land notwithstanding the absence of registration. ${ }^{126}$ Of more significance, however, for current purposes is a process for conversion of customary land to registered land under the act. Division 1 of part $\mathrm{V}$ of the act sets out a procedure to extinguish customary title to land in order to allow registration of title to perpetual or fixed term estates under the act. The act defines customary land as 'any land ... lawfully owned, used or occupied by a person or community in accordance with current customary usage'. ${ }^{127}$ The act allows transactions or dispositions of interests in customary land according to current customary usage. ${ }^{128}$ No other mechanism for the sale or lease of customary land is provided under the act, and the effect is to maintain the colonial prohibition on alienation of customary land other than to the State. ${ }^{129}$

A general prohibition on alienation of customary land first emerged in 1914 as a result of concerns, complaints and conflict caused by speculative transactions in places such as Honiara by European traders and purported chiefs. ${ }^{130}$ While, as in the case of Honiara, the private acquisition of land prior to 1914 retained retroactive validity - unless recommendations for restitution were made under the various Commissions of Enquiry - the Solomons Land Regulation 1914 interposed the state as an essential intermediary in the grant of statutory interests in customary

121 Land and Titles Act 1969 (Solomon Islands) s 117 (1).

122 Ibid.

123 Ibid s 110.

124 Ibid s 229 (2).

125 Ibid s 224(1)(b).

126 See, eg, the Real Property Act 1900 (NSW) s 42(1)(d) (providing that a registered proprietor of an interest in land is subject to the interest of a tenancy not exceeding 3 years).

127 Land and Titles Act 1969 (Solomon Islands) ch 133 s 2(1)(b) (definition of 'customary land').

128 Ibid s 240. The act further provides for the voluntary acquisition or lease of land by the Commissioner of Lands or any Provisional Assembly: s 60. Division 2 of part V allows for compulsory acquisition of customary land for a public purpose.

129 See Heritage Park Hotel Ltd v Commissioner of Lands [2016] SBHC 146, [15]-[16] (High Court of Solomon Islands).

130 For a discussion of reasons for the prohibition on land alienation, see Heath (n 103) 141-8. 
land. ${ }^{131}$ The rationale was protective, but the effect was to elevate the state as the sole source of freehold estates in land. ${ }^{132}$ Part V of the act further sets out protective measures for the State to act as an intermediary for the conversion of customary land to alienable land. For example, an Adjudication Officer must identify the purported owners or their authorised representatives in order for their names to be included in a draft agreement for purchase or lease to the Commissioner of Lands or Provincial Assembly. ${ }^{133}$ This agreement must be publicised to allow for people to make a claim against those whose names appeared on the agreement. ${ }^{134}$ In $S M M$ Solomon Ltd v Axiom KB Ltd, the Solomon Islands Court of Appeal held that failure to comply with the protective requirements of part $\mathrm{V}$ resulted in a failure to convert customary land to alienable land under the act. ${ }^{135}$ In other words, there was no customary land to register because part $\mathrm{V}$ was designed to serve the purposes of protection under the objectives of the act. ${ }^{136}$

In cases of purchase or lease of customary land, the Commissioner of Lands issues an order vesting the perpetual estate either in the Commissioner on behalf of the government, or the Provisional Assembly on behalf of the people of the province. ${ }^{137}$ The effect is that these representatives of the state hold an indefeasible perpetual estate under which discretion lies to grant perpetual, freehold or leasehold estates over all or part of the land. Moreover, the act establishes a procedure where there are more than five co-owners of customary land for which conversion to registrable land takes place. ${ }^{138}$ It stipulates that up to five persons may register as the joint proprietors on a statutory trust of a perpetual estate in land. ${ }^{139}$ The joint owners are required, under the act, to produce to the registrar a statutory declaration which contains the names of beneficiaries, a description or name of the customary land holding group, and, 'far as is practicable, the interests of the persons beneficially interested' ${ }^{140}$ While the joint owners as registered statutory trustees hold indefeasible registered estates in the land, there is substantial evidence that the appointment of trustees, and persistent failures to identify beneficiaries in accordance with the act, has been a major source of ongoing conflicts in the Solomon Islands. ${ }^{141}$ This conflict includes peri-urban land outside Honiara town boundaries in which informal leases or possessory agreements have been made by settlers with registered statutory trustees of land. ${ }^{142}$

131 Solomons Land Regulation 1914 (Solomon Islands) ss 8, 10.

132 See, eg, ibids 5.

133 Land and Titles Act 1969 (Solomon Islands) s 62(b).

134 Ibid ss 63-4.

135 [2016] SBCA 1, 66-7 [352]-[361].

136 Ibid.

137 Land and Titles Act 1969 (Solomon Islands) ch 133 ss 69(1)(a)(iv), 69(1)(c)(iv).

138 Ibid s 195.

139 Ibid ss 195, 200.

140 Ibid s 195(3).

141 See generally Rebecca Monson, 'From Taovia to Trustee: Urbanisation, Land Disputes and Social Differentiation in Kakabona' (2015) 50(4) Journal of Pacific History 437, 442-8.

142 Ibid. See also Rebecca Monson, 'Women, State Law and Land in Peri-Urban Settlements on Guadalcanal, Solomon Islands' (Justice for the Poor Briefing Note, World Bank, April 2010). 


\section{Guadalcanal and the Tensions}

Guadalcanal landowners continue to contest the land acquisition processes that formed the basis for Honiara town land. ${ }^{143}$ In 1988, a 'Petition by the Indigenous People of Guadalcanal' to the national government included the return of alienated land within the town boundaries of Honiara, and the repatriation of informal settlers to their home islands. ${ }^{144}$ These demands were repeated in a further petition of 1999, which also demanded relocation of the capital away from Guadalcanal Island. ${ }^{145}$ During the period of the Tensions, there was forced expulsion of as many as 20,000 people from land in and around Honiara. ${ }^{146}$ Most of those expelled returned to the island of Malaita. ${ }^{147}$ Many have now returned, along with other migrants, and have contributed substantially to the rapid regrowth of informal settlements in greater Honiara, which includes peri-urban areas that are within Guadalcanal Province's administration. ${ }^{148}$ In fact, there are estimates of growth per annum of around $12 \%$ in at least some of the large informal settlements in Honiara for the period from 1999-2009. ${ }^{149}$ The Tensions thus highlight the way in which the purported indefeasibility of title vested in the Commissioner of Lands has not resolved contestation over the acquisition of land by European settlers, and the subsequent migration of non-Guadalcanalese to settlements in Honiara. ${ }^{150}$ These circumstances deeply affect the functioning of the Solomon Islands state, as the proprietary foundations of the administrative capital offer a veneer of legal certainty without establishing necessarily secure or legitimate rights to land. ${ }^{151}$

143 For a discussion, see Solomon Islands Truth and Reconciliation Commission, Confronting the Truth for a Better Solomon Islands (Final Report, February 2012) vol 1, 54.

144 Petition from the Indigenous People of Guadalcanal to Solomon Islands Government, February 1988 (copy on file with authors).

145 See Kieran McGovern and Bernard Choulai, 'Case Study of Solomon Islands Peace and Conflict-Related Development Analysis’ (Human Development Report No 2005/33, United Nations Development Programme, 2005) [2].

146 Clive Moore, Making Mala: Malaita in Solomon Islands 1870s-1930s (Australian National University Press, 2017) 24 ('Making Mala'). See Solomon Islands Truth and Reconciliation Commission (n 143) 54-5.

147 See Moore, Making Mala (n 146) 24.

148 Solomon Islands Government, '2009 Population and Housing Census: Report on Migration and Urbanisation' (Solomon Islands National Statistical Office, 2009) 6 ('2009 Census'). See also Debra McDougall, 'Lost Passports? Disconnection and Immobility in the Rural and Urban Solomon Islands' [2017] (144-145) Journal de la Société des Océanistes 63.

1492009 Census (n 148) 21-2.

150 See generally Matthew G Allen, Greed and Grievance: Ex-Militants'Perspectives on the Conflict in Solomon Islands, 1998-2003 (University of Hawai'i Press, 2013). See generally Tarcisius Tara Kabutaulaka, 'Beyond Ethnicity: The Political Economy of the Guadalcanal Crisis in Solomon Islands' (Working Paper No 01/1, State, Society and Governance in Melanesia, Australian National University, 2001); Matthew G Allen, 'Land, Identity and Conflict on Guadalcanal, Solomon Islands' (2012) 43(2) Australian Geographer 163.

151 See further Matthew Allen and Sinclair Dinnen, 'Beyond Life Support? Reflections on Solomon Islands after the Regional Assistance Mission’ (2016) 3(1) Asia and the Pacific Policy Studies 6, 1011 . 


\section{Migration and the Growth of Informal Settlements}

The post-war establishment of the capital at Honiara substantially strengthened a trend of inter-island migration to Guadalcanal. ${ }^{152}$ According to the 2009 census, migration rates were recorded as 'very high around Honiara and on the Guadalcanal Plains'. ${ }^{153}$ Honiara was rated as 'the most densely populated area ... with 2,953 people per square kilometres [sic]'. ${ }^{154}$ Within the 22.73 square kilometres that make up the town lands of Honiara, ${ }^{155}$ approximately $35-40 \%$ of the inhabitants live in informal settlements - either in temporary or makeshift housing. ${ }^{156}$ These informal settlements are situated mostly on the periphery of the city. ${ }^{157}$ At least six of these settlements have encroached on customary land outside the town boundaries. ${ }^{158}$ Many more small settlements are increasing rapidly in hard-to-reach areas along ravines on the edges of creeks. ${ }^{159}$ There are also estimates from 2006 that as much as $33 \%$ of the 9,000 houses in Honiara were built without planning approvals. ${ }^{160}$

The widely-used term 'informal settlements' encompasses the Informal Settlement Zones identified in maps prepared by the Ministry of Land, Housing and Survey ('Ministry'). ${ }^{161}$ The settlements are classified as informal because their residents did not acquire land from registered holders of perpetual or fixed term estates in Honiara. ${ }^{162}$ However, commencing in the mid-1960s, the Ministry began to issue Temporary Occupation Licenses ('TOL') to members of Informal Settlement Zones. These licences required payment of an annual rent as a condition for renewal. ${ }^{163}$ Although TOLs are still used at times as an evidentiary basis for informal transactions, the TOL program is all but defunct as the Ministry collects

152 See 2009 Census (n 148) 17-19.

153 Ibid 10.

154 Amillah S Rodil and Maria Adelaida Antonette Mias-Cea, 'Cities and Climate Change Initiative: Honiara Solomon Islands Climate Change Vulnerability Assessment' (Abridged Report, United Nations Human Settlements Programme, 2014) 2.

155 Hou and Kudu (n 109) 8. See generally Helen Esther Maebuta and Jack Maebuta, 'Generating Livelihoods: A Study of Urban Squatter Settlements in Solomon Islands' (2009) 24(3) Pacific Economic Bulletin 118, 119-29.

156 Alexei Trundle and Darryn McEvoy, 'Honiara Urban Resilience \& Climate Action Plan: A Joint Strategy for the Honiara City Council and the Solomon Islands Government' (UN-Habitat Cities and Climate Change Initiative, RMIT Climate Change Adaptation Program, 2016) 8.

157 Amillah S Rodil and Maria Adelaida Antonette Mias-Cea, 'Cities and Climate Change Initiative: Honiara Solomon Islands Climate Change Vulnerability Assessment' (Abridged Report, United Nations Human Settlements Programme, 2014) 13.

158 Hou and Kudu (n 109) 8.

159 Reginald Reuben and John H Lowry, 'Effectiveness of Evacuation Facilities in Honiara City, Solomon Islands: A Spatial Perspective' (2016) 82(1) Natural Hazards 227, 230.

160 United Nations Human Settlements Programme, Solomon Islands National Urban Profile (Report, 2012) 20 .

161 See Meg Keen and Luke Kiddle, 'Priced Out of the Market: Informal Settlements in Honiara, Solomon Islands' (In Brief No 2016/28, State, Society and Governance in Melanesia, Australian National University, 2016).

162 See Greater Honiara Main Report (n 113) n 2. See also Joseph D Foukona and Matthew G Allen, 'Urban Land in Solomon Islands: Powers of Exclusion and Counter-Exclusion' in Siobhan McDonnell, Matthew G Allen and Colin Filer (eds), Kastom, Property and Ideology: Land Transformations in Melanesia (Australian National University Press, 2017) 85, 91-2.

163 Foukona and Allen (n 162) 91-2. 
little or no TOL rental revenue, ${ }^{164}$ and the names and numbers of households in TOL areas rarely reflect the original licensees. The current policy is to convert TOLs to fixed-term estates ('FTE'), as well as to grant new FTEs on application by informal settlers outside 'danger zones'. However, with 'an unimproved land value charge of SBD40-70,000 (AU\$7-12,000) [for an FTE], plus annual land rental and council rates' ${ }^{165}$ and limited capacity in the Ministry, even the current Acting Commissioner for Lands concedes that, without significant increases in Ministry funding and capacity, the number of informal settlements without TOLs or FTEs will continue to increase at significant rates in Honiara. ${ }^{166}$

Along with other cases of urbanisation in the Global South, the fundamental causes of informal settlements in Honiara include poverty, migration and the undersupply of serviced land and housing. ${ }^{167}$ As a matter of law however, it is notable that settlers are classified as 'informal' because the Commissioner of Lands holds indefeasible title under the Land and Titles Act, and settler options for formalisation of rights in law are limited to prohibitively costly applications for FTEs. The larger informal settlements are long-term in nature; there are few prospects of eviction; and yet the Land and Titles Act does not allow claims of adverse possession against the Commissioner of Lands. ${ }^{168}$ Further, the possibility of equitable remedies based on claims such as estoppel, where for example Members of Parliament have encouraged acts of settlement, has not been explored in the courts of the Solomon Islands. ${ }^{169}$ In this way, the core principles of Torrens law in Solomon Islands have played a role in the growth of 'informal' settlements in Honiara. To deny proprietary rights to long-term possessors, as a result of indefeasibility provisions inherited from a colonial regime, is to relegate the vast majority of poor and migrant households to a technical status of illegality. There is no doubt that there are public policy concerns to prevent settlements emerging in hazardous zones, as is now occurring at an alarming rate. However, the default legal position that long-term occupiers of informal settlements lack claims against the Commissioner of Lands, either in adverse possession or, as a matter of practice in equity, does nothing to improve living circumstances in large numbers of settlements which are long-term in nature.

\section{E Conceptualisations of Property in Informal Settlement Zones}

There is further evidence of social conceptions of entitlements with proprietary characteristics in the informal settlement zones of Honiara. While these expectations of entitlements resist the proprietary/personal distinctions of English

164 See generally Hou and Kudu (n 109) 15.

165 Meg Keen and Alan McNeil, 'After the Floods: Urban Displacement, Lessons from Solomon Islands' (Discussion Paper No 13, State, Society and Governance in Melanesia, 2016) 2.

166 Interview with Alan McNeil, Acting Commissioner for Lands, Ministry for Lands, Housing and Survey (Daniel Fitzpatrick, Breakwater Café, Honiara, 12 December 2018).

167 See Satish Chand and Charles Yala, 'Informal Land Systems within Urban Settlements in Honiara and Port Moresby' in Australian Agency for International Development (ed), Making Land Work (2006) vol 2 85, 89. See also Keen and Kiddle (n 161).

168 Land and Titles Act 1969 (Solomon Islands) ch 133 s 224(1)(b).

169 See Foukona and Allen (n 162) 101. 
law, it is fair to say that they are not simply a product of long-term possession, or a general absence of eviction efforts by the government. First, there is a widespread (but not universal) reliance on wantok (family or clan) affiliations within settlements as a basis for social ordering, including the entitlements of new entrants to access land. ${ }^{170}$ Almost all longstanding informal settlements in Honiara commenced as areas of migration for people from particular islands, or distinct ethno-linguistic parts of islands. For example, in the early 1950s migrants from Lau Lagoon in north-eastern Malaita built one of Honiara's earliest informal settlements at the Fishing Village in Kukum. The settlement known as White River was identified as a site for Polynesian migrants from Tikopia, Sikaiana, Rennell and Bellona. ${ }^{171}$ Honiara's largest informal settlement, known as Aekafo-Feraladoa, commenced as a site for migrant Malaitan workers in the late 1960s. ${ }^{172}$ At the time of the 2009 census, the settlement consisted of 822 households with a total estimated population of 5,183 - majority of them continue to identify as originating from Malaita. ${ }^{173}$

The wantok elements of informal settlements in Honiara encompass land access practices that are compatible, at least in a sociocultural sense, with customary mechanisms in home or originating island environments. ${ }^{174}$ That is, new migrants request permission from wantok leaders, affiliates or associations to clear, cultivate and build on land in areas understood to be under the control of the wantok-associated group. ${ }^{175}$ At the same time, some caution is warranted for wantok explanations of social ordering within informal settlements as there are also Honiara-specific processes such as intermarriage among groups, the influence of church affiliations within a settlement, and the role of management committees which may have wantok derivations, but also now involve mechanisms such as elections and written constitutions. ${ }^{176}$ The urban elements of settlement ordering also include proprietary practices such as requirements to rent land and housing in informal settlements. These practices not only indicate the emergence of a land market beyond simple family-based agreements to clear and build on land, but also forms of social differentiation and hierarchy where long-term settlements are considered as holding rights which are capable of rental to a newcomer.

Rodolfo Maggio develops a further point about the social ordering of property in informal settlements from a study of the Gilbert Camp settlement that straddles the town boundary on the southern edge of Honiara. ${ }^{177}$ Long-term residents of

170 For a discussion of the wantok system: see Gordon Leua Nanau, 'The Wantok System as a Socioeconomic and Political Network in Melanesia' (2011) 2(1) OMNES: The Journal of Multicultural Society 31.

171 Maggio (n 105) 54.

172 Darryn McEvoy, David Mitchell and Alexei Trundle, 'Land Tenure and Urban Climate Resilience in the South Pacific' [2019] Climate and Development 1, 7.

173 David Mitchell and Darryn McEvoy, Land Tenure and Climate Vulnerability (Report No 3/2019, United Nations Human Settlements Programme, 2019) 31.

174 See McEvoy, Mitchell and Trundle (n 172) 9.

175 See generally Clive Moore, 'Honiara: Arrival City and Pacific Hybrid Living Space' (2015) 50(4) Journal of Pacific History 419, 434-5.

176 See generally Ibid 429-32.

177 Maggio (n 105). 
Gilbert Camp recall that the town boundary has moved on a number of occasions since the 1960s. ${ }^{178}$ One settler built a house without customary approval outside town lands in the 1970s, and subsequently obtained a TOL when the town boundary was extended to include his land. ${ }^{179}$ Another settler initially paid money to a customary land owner, on the basis that the land was outside the town boundary, but would not do so again because he now believes that the assumption about the boundary was mistaken. Similarly, a further settler paid money to a customary land owner but later discovered that the land was within the town boundary. ${ }^{180}$ Rodolfo concludes that

[t]he people of Gilbert Camp have their own ideas regarding the nature of the town boundary, the way it 'behaves' and what to expect from it. For them, it is an invisible line that moves independently of their will, but which has a critical impact on their lives. ${ }^{181}$

\section{F Property and Sovereignty in the Solomon Islands}

The Solomon Islands illustrates the co-option of Torrens law to provide private law foundations for control over urban lands without the application of doctrines of Crown title. In this sense, the private law of property does not provide autonomy to citizens against the state, but rather provides indefeasible legal title to the state itself. As in the case of Crown title in the Philippines, the legal title of the state overlays, rather than replaces, social mechanisms of property order based around possession, investment and group relationships. As a result, the law serves more to construct or project the territorial authority of the state over urban land, rather than provide tenure security to customary owners claiming dispossession, or poor migrants to urban areas. Further, as discussed above, the mechanisms to convert customary land into alienable land require acquisition by the state before registrable titles are issued. The state, therefore, stands as gatekeeper at the legal boundaries of custom and statute in ways which sharpen distinctions between social and legal understandings of property, and - as in the case of Gilbert Camp settlement - cause bewilderment as to the notional demarcations of state law.

\section{CONCLUSION}

Positivist preferences for hard-edged, state-centric laws focus on the costs of information and exchange. All else being equal, positivist property rules administered by the state, allocating freehold rights derived from the state, are the optimal mechanism for reducing the information and exchange costs of access to resources. The Torrens principles of title by registration, and indefeasibility of registered title, creates bright-line rules where registered interests override unregistered interests, and information about registered interests lie in a public register. The necessary assumption is that Torrens law ipso facto has desired

178 Ibid 154-5.

179 Ibid 155.

180 Ibid 155.

181 Ibid 156. 
results, either because of coercive enforcement by the state, or because their comparative efficiency induces compliance as a result of voluntary transition from alternative institutional arrangements. However, the cases of informal settlements in the Philippines and the Solomon Islands illustrate the misplaced assumptions of Torrens law in comparative contexts, particularly in circumstances where the authority of the state is peripheral, weak or contested. At the limits of centralised administrative control, the assumptions of simplicity and certainty underpinning Torrens law have little use as a normative guide to legal policy, because they assume both a capable territorial state, and a set of registered rights, which may not at all be reflective of landholding reality. In these circumstances, positivist law does not have desired effects because extra-legal or informal landholders are not able to comply with law, for reasons of poverty or exclusion, and continue with alternative methods of proprietary ordering on the basis of allodial concepts such as possession, custom, transactions and family or community networks. 